\title{
The Effect of Liquidity, Leverage, and Working Capital Turn on Profitability
}

\author{
Imam Hidayat ${ }^{1}$, Filla Oktapia Sulistia Dewi ${ }^{2}$ \\ 1,2Universitas Muhammadiyah Tangerang \\ 1,2Jalan Perintis Kemerdekaan I Babakan No.33, Cikokol, Kec. Tangerang, Kota Tangerang, \\ Banten 15118 \\ e-mail: imam accounting@yahoo.com ${ }^{1}$, fillaoktapiasd@gmail.com²
}

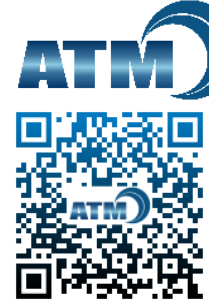

Author Notification 13 January 2022 Final Revised 10 February 2022 Published 1 January 2023

\section{To cite this document :}

Hidayat, I., \& Dewi, F.O.S. (2023). The Effect of Liquidity, Leverage, and Working Capital Turn on Profitability. APTISI Transactions on Management (ATM), 7(1), 60-68.

DOI :

https://doi.org/10.33050/atm.v7i1.1832

\section{Abstract}

The purpose of this research is to analyze the effect of liquidity, leverage, and working capital turnover on profitability in coal mining companies listed on the Indonesia Stock Exchange from 2017 to 2020. The data used in this study is quantitative. The data used is secondary data. The Sampling technique used is purposive sampling, and there were 12 firms with research for four years; this obtained 48 observations. The data analysis method used in this study is Panel data regression analysis using reviews 9. The $F$ test result is an F-statistic of $143.6753>F$ Table (2.82) and a Prob (F-statistic) value of $0.000000<0.05$, which means liquidity, leverage, and working capital turnover have a significant effect on profitability. The results of the liquidity $t$-test are a t statistic (1.198727) < t table (2.01537) and the value of Prob. $0.2371>0.05$ means that liquidity has no significant effect on profitability. The results of the $t$ test leverage $t$ statistic (20.47374) $>t$ table (2.01537) and the value of Prob. $0.0000>0.05$ means that leverage has a significant effect on profitability. The results of the t-test of working capital turnover $t$ statistic $(0.986827)<t$ table $(2.01537)$ and the value of Prob. $0.3291>0.05$ means that working capital turnover has no significant effect on the profitability of coal mining sub-sector companies listed on the Indonesia Stock Exchange.

Keywords: profitability, liquidity, leverage, working capital turnover

\section{Introduction}

Every company that is founded has a goal. The goal of most companies is to maximize profits (profit). Achieving company goals often cannot be done quickly. Various obstacles confront the company in its efforts to achieve its goals. If the company has adequate profitability, the company has the opportunity to maintain its business sustainability. By measuring company profits, companies analyze financial statements using financial ratios.

Profitability is one of the essential indicators to measure a company. Profitability ratios are used to show how much profit or profit derived from the company's performance affects the recording of financial statements and must be by the company's financial accounting standards. 
The following is a graph of the average profitability (ROA) for the period 2017 to 2020 :

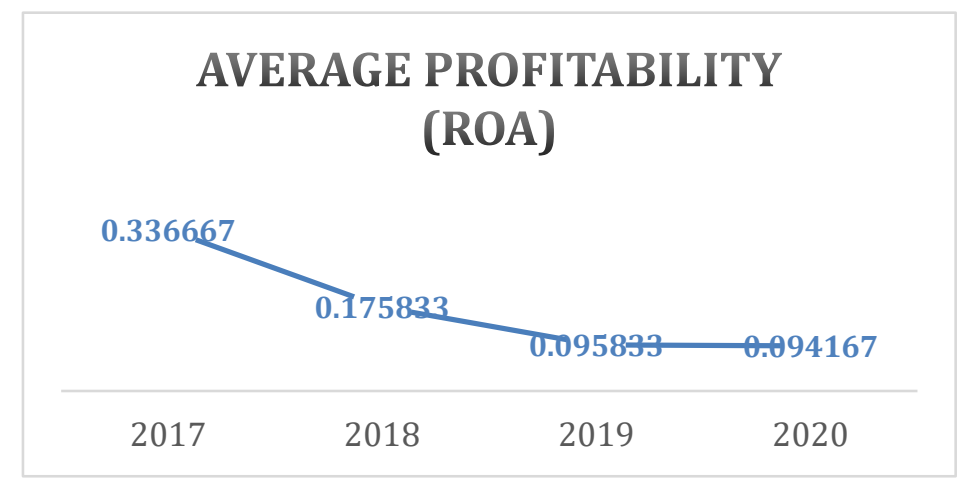
Figure 1. ROA of the Coal Mining Sub-Sector listed on the Indonesia Stock
Exchange (IDX) for the 2017-2020 period.

Based on the graph above, coal mining companies listed on the Indonesia Stock Exchange (IDX) experience fluctuating conditions every year; from 2018 to 2020, it has decreased.

Liquidity shows the company's ability to meet its financial obligations that must be fulfilled immediately or its ability to meet its financial obligations at the time of collection[1]. The general understanding of liquidity (liquidity) refers to its ability to meet its short-term obligations. Companies that can pay such a large amount so that they can fulfill all their financial obligations that must be met, that the company is liquid, and vice versa, companies that cannot pay are called illiquid. Liquidity is proxied by the Current Ratio (CR), a ratio that measures company liquidity by comparing current assets with current liabilities. In terms of profitability, a high current ratio is not necessarily good. The results of previous research conducted by Bunga and Sofie [2] regarding the effect of liquidity on profitability stated that liquidity had a significant positive effect on profitability. However, different results regarding the effect of liquidity on profitability were found from research conducted by Wahyuliza and Dewita [3], which stated that liquidity has a significant negative effect on profitability.

Leverage is to measure the level of solvency in the company[4]. In other words, the solvency ratio is the company's ability to repay long-term debt and short-term debt. This means that leverage is the use of all fixed assets in increasing the company's income. In the above understanding, it can be concluded that leverage is how the company is trying to fulfill its longterm debt and short-term debt. The results of previous research conducted by Henry Pandopotan Silitonga [5] regarding the effect of leverage on profitability stated that leverage had a significant effect on profitability. However, different results regarding the effect of leverage on profitability were found from research conducted by Afrisa Thomas [6], which stated that leverage did not significantly affect profitability.

Companies need funds to run their business activities, and these funds are called working capital. Companies that issue working capital are expected to return to the company quickly after selling their products so that working capital can continue to rotate within the company in each period. The working capital turnover rate requires companies to demonstrate their effectiveness. Thus, it can be said that the level of working capital turnover is high, and the company's income through its cash funds will also be high, which means the company is considered suitable for managing activities in the form of transactions in the company. The existence of a high level of working capital turnover indicates that the company has the opportunity to achieve high-profit growth in the future. The results of previous research conducted by Wahyuliza and Dewita[7] regarding the effect of working capital turnover on profitability stated that working capital turnover had a significant positive effect on profitability. However, different results regarding the effect of working capital turnover on profitability were found from research conducted by Sari[8] which states that working capital turnover has a significant negative effect on profitability. 


\section{Theoretical Foundations \\ Signaling Theory}

Signaling theory can state how companies can provide an excellent signal to users of financial and non-financial statements. [9] Moreover, this theory can also be a reference for investors to see whether the company is good or bad to be a place for investment funds. This theory explains the relationship between working capital turnover and profitability.

\section{Trade-off theory}

Trade-off theory in the capital structure is a balance of benefits and sacrifices that may occur due to the use of debt[10]. The higher the amount companies use to finance debt, the greater the risk that they will face financial difficulties because they pay too much-fixed interest to debt holders each year, and net income is uncertain. A company with a high level of leverage should maintain liquid assets at a high level because leverage increases the likelihood of financial distress[11]. This theory is used to explain the relationship between leverage and profitability.

\section{Pecking Order Theory}

Companies with a high level of liquidity will use more funding from debt when compared to companies that have a low level of liquidity[12]. Liquidity measures how much the company's ability to meet cash needs to pay short-term obligations and finance daily operations as working capital. The better the current ratio of a company, the company will gain the trust of creditors so that creditors will not hesitate to lend their funds which the company uses to increase capital which will later benefit the company. This theory is used to explain liquidity to the company's profitability.

\section{Profitability}

Profitability is the result of several company management policies and decisions, so company profitability is the company's ability to generate net income from activities carried out in the accounting period[13]. Companies can maximize their profits if their financial managers know what factors affect profitability. All factors contained in a company influence the company's ability to earn profits. In this study, Return on Assets $(R O A)$ is used as a proxy for profitability because the return on assets explains the company's ability to earn profits by using its assets.

\section{Theoretical Framework}

Based on the explanation of the theoretical framework, it can be simplified into a framework of thought. The theoretical framework in this study can be described in Figure 2 as follows:

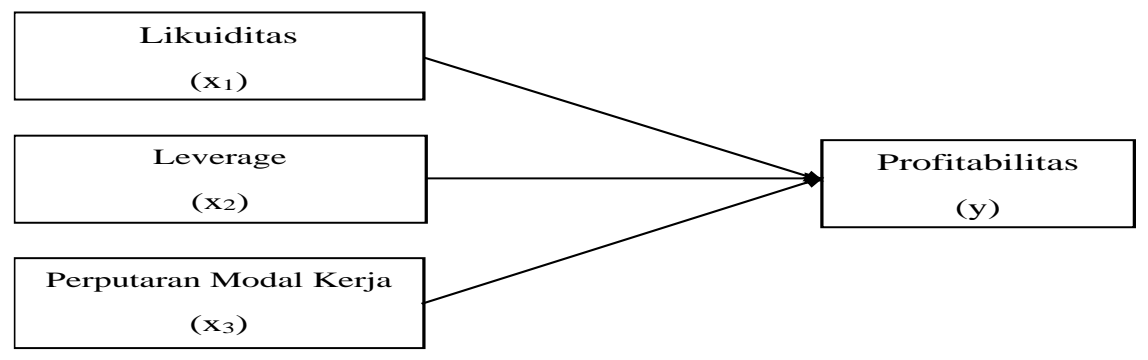

Figure 2. Theoretical Framework Model

\subsection{Hypotheses}

This study examines the causal relationship between the variables of liquidity, leverage, and working capital turnover on Profitability.

The following is the development of the hypothesis of the variables studied:

1) Effect of Liquidity on Profitability

Liquidity is a good reference for finding out whether current liabilities are met with current assets. Liquidity shows how much assets can be used like cash at maturity [14] the Pecking Order Theory, it is said that companies that have a high level of liquidity will use more funding from debt than companies that have a low level of liquidity. This description is by the research of Bunga and Sofie [15] which states that liquidity has a positive effect on Profitability. Based on the description above, the following hypotheses can be drawn: 
$\mathrm{H} 1$ : Liquidity has a positive effect on Profitability

2) The Effect of Leverage on Profitability

Leverage that is too high hurts the company's performance because the higher the level of debt means the company's interest expense will be more significant and reduce the company's profit. This description follows the research of Henry Pandopotan Silitonga, which states that leverage has a positive effect on Profitability.[16] Based on the description above, the following hypotheses can be drawn:

H2: Leverage has a positive effect on Profitability

3) Effect of Working Capital Turnover on Profitability

Good working capital management can be seen from the efficiency of working capital turnover. Working capital efficiency refers to making the available working capital, not surplus or less. Working capital turnover is the ratio between sales and working capital; high working capital turnover indicates that the company has a more vital ability to generate profits through sales. The funds issued by the company are expected to be used for further business activities. This description is by Wahyuliza and Dewita's research, which states that working capital turnover positively affects Profitability. Based on the description above, the following hypotheses can be drawn:

H3: Working Capital Turnover has a positive effect on Profitability

\section{Research Methodology}

\subsection{Research Approach}

This study uses quantitative data because it uses data in the form of numbers. The population consists of objects or subjects with specific qualities and characteristics determined by the researcher to reference. The sample in this study was taken by purposive sampling, namely sampling by determining the characteristics taken the research conducted, namely coal mining sub-sector manufacturing companies that publish financial reports for 2017-2020, companies that have complete data for this research. In this study, 48 total research samples were obtained. This research is theoretical to collect secondary data in documentation studies by studying, researching, reviewing, and reviewing the literature, articles, journals, and other sources related to the problem being studied from sources that refer to the 2017 annual report. 2020, to get the theoretical foundations expected to support data processing and secondary data obtained during the research. The data used in this study was obtained through the official website of the Indonesia Stock Exchange. The research approach used is descriptive research. The purpose of this study is to test whether there is an effect of liquidity, leverage, and working capital turnover on profitability

\section{Variable Definition and Measurement}

\section{Research Variables}

The dependent variable (dependent variable) is the affected variable or the result because of the independent variable. In this study, the dependent variable is profitability, denoted by ( $\mathrm{Y}$ ). Independent Variables (Independent Variables) are variables that affect or cause changes or the emergence of the dependent variable. The independent variables in this study are liquidity, leverage, and working capital turnover.

\section{Operational Definition}

The operational definitions of the variables used in this study can be described in the table as follows: 


\begin{tabular}{|c|c|c|c|c|c|}
\hline No & Yariabel & Definisi & Dimensi & Pengukuran & Skala \\
\hline 1. & Likuiditas (X1) & $\begin{array}{l}\text { The Current Ratio is a } \\
\text { comparison between } \\
\text { total current assets } \\
\text { and current liabilities. }\end{array}$ & $\begin{array}{l}\text { Current } \\
\text { Ratio }\end{array}$ & $\frac{\text { Aktiva Lancar }}{\text { Hutang Lancar }}$ & Rasio \\
\hline 2. & Leverage (X2) & $\begin{array}{l}\text { To measure the extent } \\
\text { to which the company } \\
\text { is financed by debt. }\end{array}$ & $\begin{array}{l}\text { Debt to } \\
\text { Assets } \\
\text { Ratio }\end{array}$ & $\frac{\text { Penjualan Bersih }}{\text { Aset Lancar - Hutang Lancar }}$ & Rasio \\
\hline 2. & $\begin{array}{l}\text { Perputaran } \\
\text { Modal Kerja } \\
\text { (X2) }\end{array}$ & $\begin{array}{l}\text { Working capital } \\
\text { turnover is used to } \\
\text { see the effectiveness } \\
\text { in managing working } \\
\text { capital. }\end{array}$ & $\begin{array}{l}\text { Working } \\
\text { Capital } \\
\text { Turnover }\end{array}$ & \begin{tabular}{|c|} 
Penjualan Bersih \\
Aset Lancar - Hutang Lancar
\end{tabular} & Rasio \\
\hline
\end{tabular}

\begin{tabular}{|c|c|c|c|c|c|}
\hline 4. & $\begin{array}{l}\text { Profitabilitas } \\
\text { (Y) }\end{array}$ & $\begin{array}{l}\text { This ratio measures } \\
\text { the overall } \\
\text { management } \\
\text { effectiveness, which } \\
\text { is indicated by the } \\
\text { size of the profit } \\
\text { obtained from sales } \\
\text { and investment. }\end{array}$ & $\begin{array}{c}\text { Return } \\
\text { On Asset }\end{array}$ & $\frac{\text { Laba Bersih }}{\text { Total Aktiva }}$ & Rasio \\
\hline
\end{tabular}

\section{Table 1. Operational definition}

\subsection{Data Analysis Method}

\section{Descriptive Statistical Analysis}

Descriptive statistics are statistics used to analyze data by describing or describing the data that has been collected as it is without intending to make conclusions that apply to the public or generalizations. Descriptive statistics function to test the variables of the sample factors used. [17] From the data management, descriptive statistics can know the maximum value, minimum value, average value (mean), and deviation of the data spread.

\section{Estimation of Panel Data Regression}

Regression analysis is one of the most popular and widely used analyzes. Regression analysis is widely used to make predictions and forecasts.[18] This analysis is also used to understand which independent variables are related to the dependent variable and determine the forms of these relationships. This study uses panel balance panel data. The regression model estimation method using panel data can be done through three approaches, including:

\section{a. Common Effect Model (CEM)}

The model without individual effect (common effect) is an estimate that combines (pooled) alltime series and cross-section data and uses the OLS (Ordinary Least Square) approach to estimate the parameters. In general, the model equation is written as follows:

$Y_{i t}=\alpha+\beta X_{i t}+\varepsilon_{i t}$

Dengan:

$Y_{i t}$ : Response variable on the unit of observation ke-i dan waktu ke-t

$X_{i t}$ : Predictor variables on the unit of observation ke-i dan waktu ke-t

$\beta$ : Slope coefficient or direction coefficient

$\alpha:$ Intercept regression model

$\varepsilon_{i t}$ : Error or error component in the unit of observation ke-i dan waktu ke-t 
b. Fixed Effect Model (FEM)

Fixed Effect Model is a model that assumes that differences between individuals can be accommodated from differences in intercepts. [19] In the fixed-effect model, each individual is an unknown parameter and will be estimated using a dummy variable technique which can be formulated as follows:

$$
Y_{i t}=\alpha_{1}+\sum_{k=2}^{N} a_{k} D_{k}+\beta X_{i t}+\varepsilon_{i t}
$$

\section{c. Random Effect Model (REM)}

Random Effect Model (REM) differences in individual characteristics and time are accommodated in the model's error. Considering that two components contribute to the formation of errors, namely individual and time, the random error in REM also needs to be broken down into errors for the time component and combined error. Thus the REM equation is formulated as follows:

$$
Y_{n}=\alpha+\beta X_{i t}+\varepsilon_{i t} ; \quad \varepsilon_{i t}=u_{i}+v_{t}+w_{i t}
$$

Where:

$u_{i}$ : Komponen error cross section

$v_{t}:$ Komponen error time series

$w_{i t}$ : Komponen error gabungan.

\subsection{Data Analysis Method}

\section{A. Descriptive Statistics}

The sample in this study is coal mining companies listed on the Indonesia Stock Exchange in 2017-2020, and it is known that there will be 22 companies in 2020.[20] Twelve companies meet the research criteria. The company's financial statements, namely 48 observations for four years. The data is processed using Eviews to obtain the following results:

\begin{tabular}{ccccc}
\hline \hline & ROA & CR & DAR & WCT \\
\hline \hline Mean & 0.175625 & 2.426458 & 0.452500 & 8.930208 \\
Median & 0.120000 & 1.715000 & 0.390000 & 3.900000 \\
Maximum & 2.070000 & 10.07000 & 3.720000 & 150.2900 \\
Minimum & 0.000000 & 0.730000 & 0.090000 & -71.10000 \\
Std. Dev. & 0.298777 & 1.940901 & 0.504547 & 32.35057 \\
& & & & 48
\end{tabular}

\section{B. Panel Data Regression}

Table 2. Descriptive statistics

$\begin{array}{llll}\text { Effects Test } & \text { Statistic } & \text { d.f. }\end{array}$


Based on the above calculation results, the value of the probability of cross-section $\mathrm{F}$ and crosssection chi-square $<(0.05)$, it can be concluded that the Fixed Effect Model (FEM) is more feasible to use.

\begin{tabular}{llll}
\hline \hline & & & \\
Cross-section random & 1.854873 & 3 & 0.6031 \\
& & & \\
\hline \hline
\end{tabular}

\section{Table 4. Uji Hausman}

Based on the results of the above calculation, the probability value (Prob.) of random crosssection > (0.05), it can be concluded that the Random Effect Model (REM) is more feasible to use.

\begin{tabular}{|c|c|c|c|}
\hline & \multicolumn{3}{|c|}{ Test Hypothesis } \\
\hline & Cross-section & Time & Both \\
\hline \multirow[t]{2}{*}{ Breusch-Pagan } & 27.58415 & 1.047630 & 28.63178 \\
\hline & $(0.0000)$ & $(0.3061)$ & $(0.0000)$ \\
\hline \multirow[t]{2}{*}{ Honda } & 5.252061 & 1.023538 & 4.437519 \\
\hline & $(0.0000)$ & $(0.1530)$ & $(0.0000)$ \\
\hline \multirow[t]{2}{*}{ King-Wu } & 5.252061 & 1.023538 & 3.338501 \\
\hline & $(0.0000)$ & $(0.1530)$ & $(0.0004)$ \\
\hline \multirow[t]{3}{*}{ Standardized Honda } & 5.844600 & 1.478103 & 2.128797 \\
\hline & $(0.0000)$ & $(0.0697)$ & \\
\hline & & & $(0.0166)$ \\
\hline \multirow[t]{2}{*}{ Standardized King-Wu } & 5.844600 & 1.478103 & 1.326450 \\
\hline & $(0.0000)$ & $(0.0697)$ & $(0.0923)$ \\
\hline \multirow[t]{2}{*}{ Gourierioux, et al.* } & -- & -- & 28.63178 \\
\hline & & & $(<0.01)$ \\
\hline
\end{tabular}

Table 5. Lagrange Multiplier Test

Based on the calculation results above, the Breusch-Pagan Cross-section Probability value < $(0.05)$, it can be concluded that the Random Effect Model (REM) is more feasible to use. 


\section{Discussion \\ Effect of Liquidity on Profitability}

Based on the results of the t-test shows that the liquidity variable does not affect profitability. No effect of liquidity on profitability indicates that increased liquidity cannot increase its profitability and fund management, especially in current assets that are less efficient. The results of this study are consistent with the results of Wahyuliza and Dewita's research but not consistent with the research of Bunga and Sofie.[21]

Effect of Leverage on Profitability

Based on the results of the t-test shows that the leverage variable affects profitability. Leverage has a positive effect on profitability seen through the coefficient of the leverage variable is positive. Thus it can be concluded that leverage has a positive effect on profitability. The effect of leverage on profitability shows that using more outstanding debt can increase profitability, and the use of debt is appropriate. The results of this study are consistent with the results of Henry Pandopotan Silitonga's research but are not consistent with the research of Afrisa Thomas.

\section{Effect of Working Capital Turnover on Profitability}

Based on the results of the t-test shows that the working capital turnover variable does not affect profitability. No effect of working capital turnover on profitability shows that working capital turnover is not high, and its use is less effective, which results in reduced sales so that the company's profitability does not increase. The results of this study are consistent with the results of Sari but not consistent with the research of Wahyuliza and Dewita.[22]

\section{Conclusion}

Based on the results of testing the data in this study, it can be concluded as follows:

1. Liquidity, as proxied by the Current Ratio, has no significant effect on profitability, or $\mathrm{Ha}_{1}$ is rejected.

2. Leverage proxied by the Debt to Assets Ratio significantly affects profitability, or $\mathrm{Ha}_{2}$ is rejected.

3. Working Capital Turnover as proxied by Working Capital Turnover has no significant effect on profitability, or $\mathrm{Ha}_{3}$ is rejected.

\section{Suggestion}

Suggestions for further researchers are to add independent variables that can affect profitability, both internal and external factors, increase the research period, which is not limited to 20172020, and add samples of other sector companies listed on the Indonesia Stock Exchange (IDX).

\section{References}

[1] Z. Kisman and D. Krisandi, "How to predict financial distress in the wholesale sector: Lesson from Indonesian Stock Exchange," J. Econ. Bus., vol. 2, no. 3, pp. 569-585, 2019.

[2] A. K. Penuam, M. Burhan, and E. Subiyantoro, "The Effect of Capital Structure and Inventory Turnover on Net Income through Net Sales in Food and Beverage Companies on the Indonesia Stock Exchange 2015-2019 Period," 2021.

[3] S. Manullang and F. Hutabarat, "Sustainable Growth and Liquidity on Profitability: A Study on Mining Sector Companies Listed at Indonesia Stock Exchange in 2018," J. AKSI (Akuntansi dan Sist. Informasi), vol. 5, no. 1, 2020.

[4] K. Rusnindita, L. Liahmad, and Y. P. Utami, "Evaluation of Cooperative Financial Performance: A Case Study of Civil Servant Cooperative," in International Joint Conference on Science and Technology, 2020, vol. 2, no. 1, pp. 56-63.

[5] H. L. Baha, "PENGARUH UKURAN PERUSAHAAN, KEPEMILIKAN INSTITUSIONAL, PROFITABILITAS DAN PERUBAHAN LABA TERHADAP NILAI PERUSAHAAN," SIMAK, vol. 19, no. 02, pp. 190-212, 2021.

[6] N. Agatz, M. Hewitt, and B. W. Thomas, "'Make no little plans': Impactful research to solve the next generation of transportation problems," Networks, vol. 77, no. 2, pp. 269286, 2021. 
[7] D. Hertina, "The influence of current ratio, debt to equity ratio and company size on return on assets," Turkish J. Comput. Math. Educ., vol. 12, no. 8, pp. 1702-1709, 2021.

[8] I. Wahyuni and S. S. A. Wibowo, "THE EFFECT OF WORKING CAPITAL ON FIRM PERFORMANCE," J. Appl. Manag. Account., vol. 2, no. 2, pp. 232-244, 2018.

[9] T. MUTIASISWI, "PENGARUH EVA DAN RISIKO PERUSAHAAN TERHADAP HARGA SAHAM MELALUI STRUKTUR MODAL PADA PERUSAHAAN PERKEBUNAN YANG TERDAFTAR DI BEI TAHUN 2011-2015." STIESIA SURABAYA, 2018.

[10] S. Wahyuni, A. Kawulur, and R. Winerungan, "Pengaruh Struktur Modal, Profitabilitas Terhadap Nilai Perusahaan Pada Perusahaan Industri Barang Konsumsi Di Bursa Efek Indonesia," J. Manaj. dan Bisnis, vol. 6, no. 1, 2021.

[11] N. Aristantya, "Pengaruh Likuiditas, Leverage, Aktivitas dan Ukuran Perusahaan terhadap Profitabilitas Perusahaan Sub Sektor Otomotif dan Komponen yang Terdaftar di Bursa Efek Indonesia." STIE Perbanas Surabaya, 2021.

[12] N. Zikrianti, J. Rinaldo, and M. Yani, "PENGARUH MEKANISMECORPORATE GOVERNANCE DAN KUALITAS KANTOR AKUNTAN PUBLIK TERHADAP INTEGRITAS LAPORAN KEUANGAN," Pareso J., vol. 3, no. 4, pp. 811-822, 2021.

[13] S. Wahyuliza and N. Dewita, "pengaruh likuiditas, solvabilitas dan perputaran modal kerja terhadap profitabilitas pada perusahaan manufaktur yang terdaftar di Bursa Efek Indonesia," J. Benefita, vol. 3, no. 2, pp. 219-226, 2018.

[14] D. A. Pratama and S. Wahyudi, "ANALISIS PENGARUH LIKUIDITAS DAN LEVERAGE KEUANGAN TERHADAP PROFITABILITAS DENGAN FIRM SIZE SEBAGAI VARIABEL CONTROL (Studi Kasus Pada Perusahaan Tekstil dan Garmen yang Terdaftar di Bursa Efek Indonesia (BEI) Tahun 2014-2019)," Diponegoro J. Manag., vol. 10, no. 5, 2021.

[15] F. A. Sitanggang, "PENGARUH LIKUIDITAS DAN LEVERAGE TERHADAP PROFITABILITAS PADA PT TELKOM INDONESIA (PERSERO), TBK YANG TERDAFTAR DI BURSA EFEK INDONESIA," J. Manaj. Terap. dan Keuang., vol. 10, no. 01, pp. 138-152, 2021.

[16] A. R. Anissa, "Pengaruh Perputaran Modal Kerja, Petumbuhan Penjualan Dan Likuiditas Terhadap Profitabilitas Pada Perusahaan Retail Yang Terdaftar Di Bursa Efek Indonesia," JRMSI-Jurnal Ris. Manaj. Sains Indones., vol. 10, no. 1, pp. 125-147, 2019.

[17] F. Sudarto, M. Mulyati, E. P. Harahap, and F. A. Nurul, "Design Of Property Sales Information System PT. Quality Property Indonesia," Aptisi Trans. Manag., vol. 4, no. 2, pp. 149-156, 2020.

[18] A. K. Badri, J. Heikal, Y. A. Terah, and D. R. Nurjaman, "Decision-Making Techniques using LSTM on Antam Mining Shares before and during the COVID-19 Pandemic in Indonesia," APTISI Trans. Manag., vol. 6, no. 2, pp. 167-180, 2022.

[19] Q. Aini, S. R. Zuliana, and N. P. L. Santoso, "Management Measurement Scale As A Reference To Determine Interval In A Variable," Aptisi Trans. Manag., vol. 2, no. 1, pp. 45-54, 2018.

[20] S. Sudaryono, U. Rahardja, and D. Apriani, "The CICES Journal Governance Performance Improvement on Quality of Current Issues (Case Study of STMIK RAHARJA)," Aptisi Trans. Manag., vol. 3, no. 1, pp. 57-64, 2019.

[21] Z. Fauziah, H. Latifah, U. Rahardja, N. Lutfiani, and A. Mardiansyah, "Designing Student Attendance Information Systems Web-Based," Aptisi Trans. Technopreneursh., vol. 3, no. 1, pp. 23-31, 2021.

[22] U. Rahardja, N. Lutfiani, and H. L. Juniar, "Scientific Publication Management Transformation In Disruption Era," Aptisi Trans. Manag., vol. 3, no. 2, pp. 109-118, 2019. 